\title{
RELIGIOZITATE, EMOȚIE, VIRTUTE ȘI SATISFACT,IE FAȚĂ DE VIAȚĂ - O ABORDARE DIN PERSPECTIVA PSIHOLOGIEI POZITIVE
}

\author{
Adrian Roșan*
}

\begin{abstract}
Religion, emotion, virtue and life satisfaction - a positive psychology approach. The premises of this study are based on the positive psychology's argument that a pragmatic society needs to be convinced that virtues are better than rewards and that exercising virtues significantly reduced distress, difunctionality and psychopathology, therefore enhancing life satisfaction by empowering: happiness (a subjective state of being), self acceptance, reverence towards life, competence, efficency, mental and physical health, rich and supportive social networks, respect towards others, marital satisfaction and healthy communities and families. The purpose of this study is the investigation of the relationship between life satisfaction (low, medium, high) and the values in action refelcted by virtues in the context of religion. The study was conducted on a sample of 252 participants who were separated into three distinct groups based on their level of life satisfaction: SSlow levels $(n=30)$. SM-medium levels $(n=57)$ and SC high levels $(n=165)$. The univariate analysis of variance showed significant differences between the three groups according to their levels of life satisfaction. This study brings to light a series of scientific proofs about the importance of life values in action in the context of religion, highlighting once more that religious education, the faith in God and the cultural context support the acquirement of virtues through institutions, rituals, role models, parabola and motivational stories (Seligman, 2002), raising implicitly life satifaction.
\end{abstract}

Keywords: emotion, religiosity, life satisfaction, values in action.

Premisele de la care pornește aceste studiu se bazează pe fundamentul psihologiei pozitive conform căreia o societate pragmatică va trebui sa fie convinsă că virtuţile sunt preferabile recompenselor şi că exersarea virtuţilor reduce semnificativ apariţia distres-ului, a disfuncţionalităţilor şi a psihopatologiei, crescând

* PhD, Associate Professor, Department of Special Education, Faculty of Psychology and Educational Sciences, Babeş Bolyai University. 
satisfacţia faţă de viaţă a oamenilor prin rezultate cum sunt : starea subiectivă de bine (fericirea), acceptarea de sine, reverenţa în faţa vieţii, competenţă, eficacitate şi măiestrie, sănătate fizică şi mintală, reţele sociale şi de suport bogate, respectul pentru alţii, muncă care produce satisfacţii, mulţumire materială și comunităţi şi familii sănătoase.

Emoţiile sunt definite de o serie de autori, ca fiind stări mentale cu funcţii intenţionale, de alţii ca fiind atât intenţionale, cât si fenomenologice; Alte studii definesc emoţiile ca fiind stări mentale de natură exclusiv fenomenologică. Conform teoriei lui Barrett (2006) care are drept punct de pornire teoria afectului central al lui Russell (2003) două componente emoţionale sunt extrem de importante: arousal-ul şi valenţa din a căror combinare se nasc afectele centrale. Russell consideră emoţiile, ca fiind constructe socio-culturale, categorii ale afectelor centrale care nu există în realitate. Din punct de vedere al valenţei, emoţiile sunt: negative (ex. tristeţea sau furia), pozitive (ex. bucuria, compasiunea) şi neutre (uimirea). Emoţiile negative se concentrează pe o problemă şi implică demersuri corective. Din punct de vedere al tendinţelor de acţiune, emoţiile pozitive stimulează comportamente prosociale, relaţiile interpersonale, exersarea abilităţilor şi dezvoltarea personală. Aceste comportamente deţin o funcţie stenică pe termen lung, pe măsură ce cresc solicitările mediului. (Haidt, 2003). Dintre emoţiilor pozitive (Ekman, 1994), amintim: bucuria, veneraţia, mândria faţă de o realizare etc. Din perspectiva dimensiunii stenice, emoţiile sunt împărţite în două categorii: funcţionale si disfuncţionale. Această dimensiune este diferită de dimensiunea valenţei, emoţiile funcţionale pot fi pozitive (ex. bucurie, amuzament, uşurare), cât si negative (ex. iritare, teamă). Emoţiile disfuncţionale pot avea o valenţă pozitivă sau negativă (ex. furie, depresie).

Watts (1996) consideră că există două paradigme de bază privind rolul emoţiilor în viaţa religioasă: (1) mişcarea carismatică care accentuează cultivarea unor emoţii pozitive intense şi importanţa acestora în experienţa religioasă şi ritualurile religioase colective (vezi de asemenea McCauley, 2000 citat de Emmons şi 
Paloutzian, 2003) şi (2) tradiţia contemplativă care accentuează calmarea pasiunii şi dezvoltarea unei aşa numite „tihne” emoţionale. Acestor două perspective privind reglarea emoţiilor li se adaugă o a treia şi anume (3) punctul de vedere ascetic (Allen, 1997 citat de Emmons şi Paloutzian , 2003 ) care leagă religia de o puternică conştientizare a emoţiilor (ceea ce numim noi astăzi cu un termen contemporan inteligenţă emoţională, vezi Golemann), precum şi exprimarea creativă a acestora.

Tehnicile de reglare a emoţiilor care îşi găsesc rădăcinile în tradiţia religioasă sunt capabile să moduleze în mod cotidian experiența noastră emoţională (Schimmel, 1997; Watts, 1996.), furnizând mecanisme de raţionalizare spirituală şi metode de control a stărilor emoţionale problematice cum sunt: furia, vinovăţia şi depresia. De asemenea, efecte emoţionale pozitive au fost obţinute şi de către persoanele care practică meditaţia Zen (Gillani şi Smith, 2001) sau cele care cultivă stările transpersonale îndelungate asociate tradiţiilor spirituale şi religioase (Mc Craty şi alţii, 1998). Literatura privind reglarea emoţiilor la vârsta adultă (Gross, 2002) ar putea fi interesată de datele furnizate de psihologia religiei, iar în mod similar cercetările din domeniul emoţiilor ar putea conştientiza în mod semnificativ influenţele religioase şi spirituale asupra producerii şi manifestării stărilor emoţionale (Hill, 1999). Conform lui Silberman (2003) se conturează trei căi prin care religia ca sistem semnificativ influenţează emoţiile: În primul rând, religia prescrie emoţii adecvate şi nivelul lor de intensitate. În al doilea rând, credinţele privind natura şi atribuirile asupra lui Dumnezeu influenţează starea de bine a persoanei (,well-being”), iar în al treilea rând religia oferă oportunitatea de a experienţia unicitatea puterii emoţiei de apropiere faţă de ceea ce numim sacru.

McCullough (2002) citat de Emmons şi Paloutzian (2003) a constatat că oamenii care se află la un nivel de spiritualitate ridicat raportează un nivel înalt al recunoştinţei în dispoziţiile afective cotidiene, la fel ca persoanele $\mathrm{cu}$ un nivel ridicat al interesului religios, religiozităţii în general şi orientării religioase interioare. Este interesant de remarcat că între orientarea religioasă utilitaristă, extrinsecă sau temporară şi nivelul recunoştinţei în dispoziţia 
afectivă cotidiană nu se constată o corelaţie semnificativă. Acest fapt conduce la concluzia că persoanele cu o orientare religioasă intrinsecă, în special acele persoane pentru care religia este un principiu fundamental de organizare a existenţei, precum şi persoanele care raportează un grad crescut de transcendenţă spirituală, trăiesc un nivel mai ridicat al recunoştinţei comparativ cu persoanele cu un nivel religios sau spiritual scăzut. Autorii acestui studiu sugerează că prezenţa recunoştinţei constituie un indicator al afectivităţii pozitive la persoanele religioase sau cu un nivel ridicat de spiritualitate, la fel ca absenţa la aceste persoane a unor simptome depresive care constituie un indicator al afectivităţii negative.

Beneficiile religiozităţii asupra stării de sănătate a persoanelor este susţinută de multe studii. Emmons şi Paloutzian (2003) definesc religiozitatea drept o caracteristică a persoanei, un sistem semnificativ de convingeri stabil în timp şi manifestat consecvent în diverse situaţii. Studiile însă privind punerea în evidenţă a conexiunii între mecanismele complexe cauzale ale religiozităţii şi starea de sănătate sunt încă la început. În mod particular o explicaţie promiţătoare în acest sens ar constitui-o studiu încadrării la nivelul experienţei religioase a emoţiilor cum sunt speranţa, dragostea, iertarea şi recunoştinţa (Ellison şi Levin, 1998). Exprimarea prin rugăciune şi recunoştinţă sunt componente cheie ale veneraţiei religioase, efectele psihologice ale mulţumirii şi recunoştinţei ar putea explica înţelegerea impactului religiei asupra sănătăţii, poate chiar drept mediator al legăturii puternice între religiozitate şi sănătatea fizică. George şi alţii (2000) consideră drept prioritate pentru cercetările viitoare asupra spiritualităţii şi sănătăţii studiul „epidemiologiei experienţei spirituale”(pag. 113), având în vedere că experienţa spirituală este o dimensiune ignorată în majoritatea cazurilor.

Sandage şi Hill (2001) trasează coordonatele unui construct al virtuţii bazându-se pe rezultate ale unor studii atât din filosofia morală, cât şi din ştiinţele sociale. Aceşti autori consideră că există 6 dimensiuni ale virtuţii: a) integrează etică şi sănătate; b) include trăsături de caracter; c) este sursă a trăsăturilor pozitive ale omului şi a capacităţii de schimbare; d) se dezvoltă într-un context cultural şi 
comunitar; e) contribuie la conturarea sensului vieţii; f) se bazează pe capacitatea cognitivă de a fi înţelept. Un alt punct care ar putea genera tensiuni este acela dacă virtuţile sunt construite ca entităţi universale sau culturale. Aceste categorii, însă nu sunt mutual exclusive. Este posibil ca o virtute în mod particular (de exemplu, iertarea) să constituie o valoare universală, dar care să fie localizată în mod specific în cadrul unor instituţii culturale sau ritualuri. Acesta ar putea semnifică că iertarea ar putea fi exprimată sau chiar definită diferit în cadrul diverselor contexte culturale sau comunităţi. Modelele individualiste ale iertării au tendinţa de a o considera drept o decizie personală de alegere, în vreme ce indivizii în cadrul diverselor colectivităţi au tendinţa să acţioneze în conexiune extrem de puternică cu normele sociale prescrise. Un accent deosebit în literatura psihologică occidentală este pus pe iertarea de către ceilalţi, iar în privinţa căinţei (Exline şi Baumeister, 2000) şi căutarea iertării celorlalţi (Sandange şi alţii, 2000) referirile bibliografice sunt relativ puţine.

Pe de altă parte, psihologia pozitivă (Seligman şi Csikszentmihaly, 2000) a realizat o clasificare sistematică a trăsăturilor şi virtuţilor umane într-o taxonomie comprehensivă (Peterson şi Seligman, 2002). Modelul valori-în-acţiune (VIA) sau a virtuţilor din perspectiva psihologiei pozitive (Peterson şi Seligman 2002) conţine 6 virtuţi şi 24 de valori în acţiune care pot fi regăsite în toate culturile şi tradiţiile religioase:

1) înţelepciunea şi cunoaşterea (curiozitatea, plăcerea de a învăţa, discernământul, inventivitatea, inteligenţa socială, simţul perspectivei);

2) curajul (vitejia, perseverenţa, integritatea);

3) umanitatea şi iubirea (bunătatea şi capacitatea de a iubi şi a te lăsa iubit);

4) dreptatea (responsabilitatea cetățenească, imparţialitatea, spiritul de conducere);

5) cumpătarea (autocontrolul, prudenţa, umilinţa);

6) transcendenţa (aprecierea frumuseţii, gratitudinea, speranţa, spiritualitatea, iertarea, simţul umorului, entuziasmul), trăirile emoţionale care apar în contextul 
diferitelor experienţe sau manifestări religioase şi satisfacţia

vieţii în contextul credinţei religioase.

În cadrul studiului nostru referitor la relaţia dintre valorile în acţiune şi satisfacţia în faţa vieţii în contextul credinţei religioase neam raportat la următoarele definiţii operaţionale ale credinţei religioase şi satisfacţiei faţă de viaţă.

În cadrul credinţei religioase am avut în vedere religiozitatea cu următoarele dimensiuni:

- Practici religioase private incluzând rugăciunea și cititul Sf. Scripturi

- Importanța autodeclarată a religiei în diverse aspecte ale vieții

- Experiențe spirituale și religioase, incluzând trăirile privind prezența și dragostea lui Dumnezeu

- Convingeri teologice și religioase

În privința satisfacției față de viață am utilizat un instrument The Satisfaction With Life Scale (SWLS) care măsoară satisfacția față de viața ca un întreg. Prin urmare, nu am urmărit evaluarea satisfacţiei faţă de viaţă pe domenii cum ar fi sănătate sau veniturile, ci am încercat să integrăm acele domenii pe care oamenii le aleg ca fiind importante în viaţa lor. SWSL este recomandată ca un instrument complementar scalelor care evaluează psihopatologia sau starea de bine emoţională, deoarece evaluează aprecierile conştiente ale persoanei asupra proprie vieţi pe baza propriilor criterii.

Domeniile comune satisfacției vieții ca întreg sunt următoarele:

- relaţiile sociale

- performanța la școala/locul de muncă

- nivelul personal (satisfacţia faţă de sine, viaţa spirituala, dezvoltare personala, timp liber).

\section{Scopul studiului}

○ Investigarea relaţiei dintre nivelul satisfacției față de viaţă (scăzut, mediu, crescut) și valorile în acțiune reflectate în virtuţi în contextul religiozității 


\section{Obiectivele studiului}

○ investigarea dimensiunilor virtuţilor (cunoaşterea şi înţelepciunea, curajul, umanitatea şi iubirea, dreptatea, cumpătarea şi transcendenţa) în contextul religiozității

○ identificarea valorilor în acţiune (modelul VIA) în contextul religiozității

- identificarea trăirile emoţionale care apar în contextul diferitelor experienţe sau manifestări religioase

- investigarea relaţiei dintre valorile în acţiune, emoţii şi satisfacţia în viaţă în contextul religiozităţii

\section{Predicții}

- Persoanele cu un nivel crescut al religiozității autodeclarate vor avea un nivel crecut al satisfacției față de viață

- Persoanele cu un nivel crescut de religiozitate autodeclarată vor experienția predominant emoții pozitive funcționale în legătură cu evenimentele și manifestările religioase

- Vor există diferențe semnificative între persoanele cu diferite nivele de satisfacție a vieții (scăzut, mediu, scăzut) și aplicarea valorilor în acțiune reflectate în virtuți (VIA) în propria viață

\section{Instrumentarul de investigaţie}

- Chestionarul de evaluare a virtuţilor şi trăsăturilor de caracter (Peterson şi Seligman, 2002)

- Scala de satisfacţie a vieţii (SWSL), Diener şi alţii, 1985)

- Evaluarea emoțiilor în contextul religiozității (adaptare din Geneva Appraisal Questionnaire) 


\section{Participanții la studiu}

Alegerea participanților a fost voluntară și aplicarea chestionarul a fost realizată online. Grupul de participanţi a fost format din 252 de participanti, cu vârsta medie de 33 de ani, cuprins în intervalul 18-65 ani). În figura 1 sunt reprezentate valorile procentuale privind configurația grupului de participanţi în funcție de gen: $83,41 \%$ feminin și $16,59 \%$ masculin.
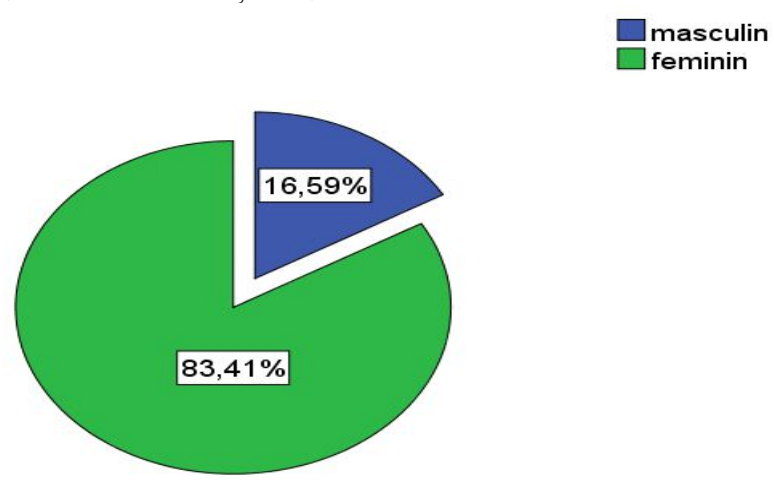

Figura 1. Reprezentarea grafică a grupului de participanți în funcție de gen

În figura 2 este redată sub formă grafică valoarea procentuală a numărului de participanți în funcție de regiunea geografică din care provin. 


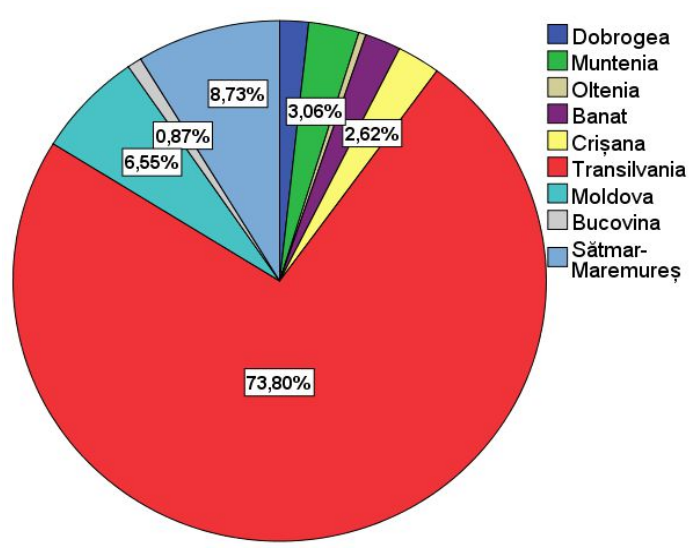

Figura 2. Reprezentarea grafică a grupului de participanți în funcție de regiune

În figura 3 și 4 , redăm valorile proncetuale ale valorilor însumate în funcție de variabila ultima școală absolvită și respectiv, statutul în momentul completării chestionarului.

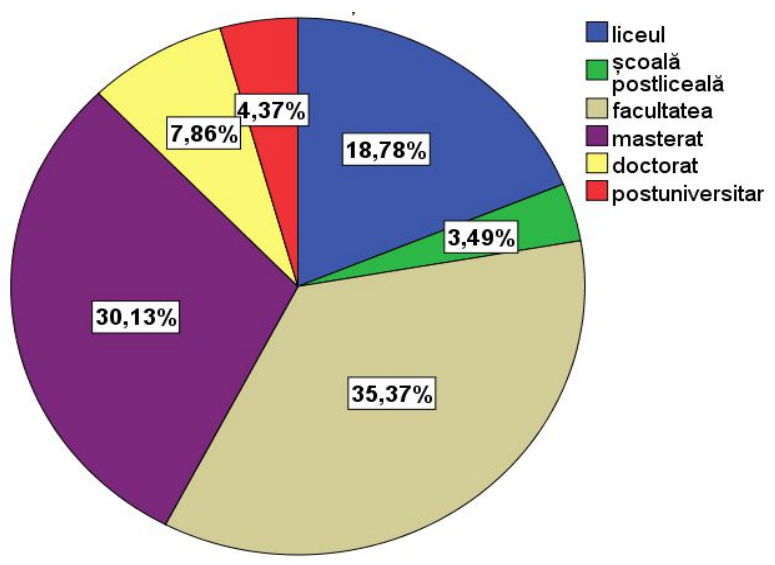

Figura 3. Reprezentarea grafică a grupului de participanți în funcție de ultima şcoală absolvită 


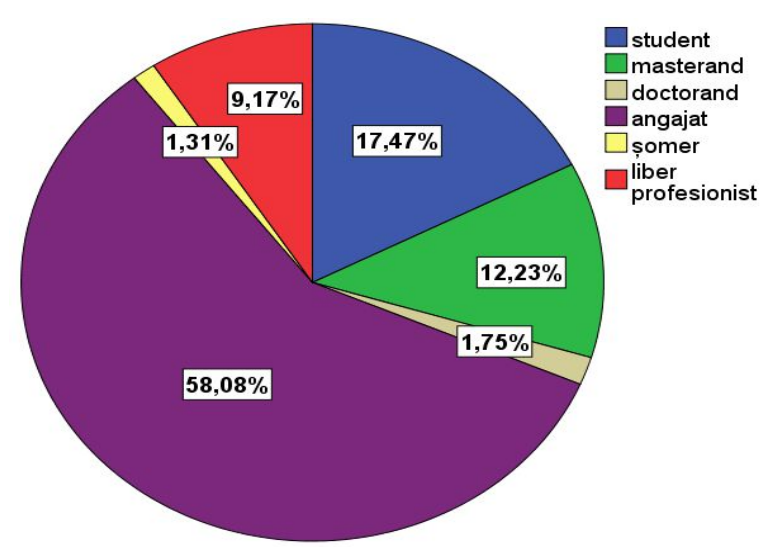

Figura 4. Reprezentarea grafică a grupului de participanți în funcție de statutul actual

\section{Rezultate înregistrate}

În figura 5, se pot observa frecvențele de răspuns ale participanților în funcție de variabila cultul declarat, în raport cu cultele creștine recunoscute de legislația din Romînia. Prin participanţi, majoritatea $(\mathrm{N}=167)$ s-au declarat ca fiind de religie ortodoxă, penticostală $(\mathrm{N}=17)$, greco-catolică $(\mathrm{N}=13)$, romanocatolică $(N=7)$, baptistă $(N=6)$, adventistă $(N=4)$, reformată $(N=4)$, evanghelică $(\mathrm{N}=2)$ și câte un participant de religie evanghelicluteran, evreu mozaic și unitarian. Dintre participanți $(\mathrm{N}=6)$ s-au declarat ca făcând parte din alte religie decât cele menționate de noi în chestionarul online.

Din totalul participanților $89,52 \%$ au declarat că, ei cred în Dumnezeu și $10,48 \%$ că nu cred. În ceea ce privește tăria și credința în Dumnezeu, 40,61\% și-au declarat acordul total, 37,12\% și-au exprimat acordul, 10,04\% s-au declarat neutri, 4,80\% dezacord și $7,42 \%$ și-au declarat dezacordul total în ceea ce privește tăria credinței în Dumnezeu (figura 6). 


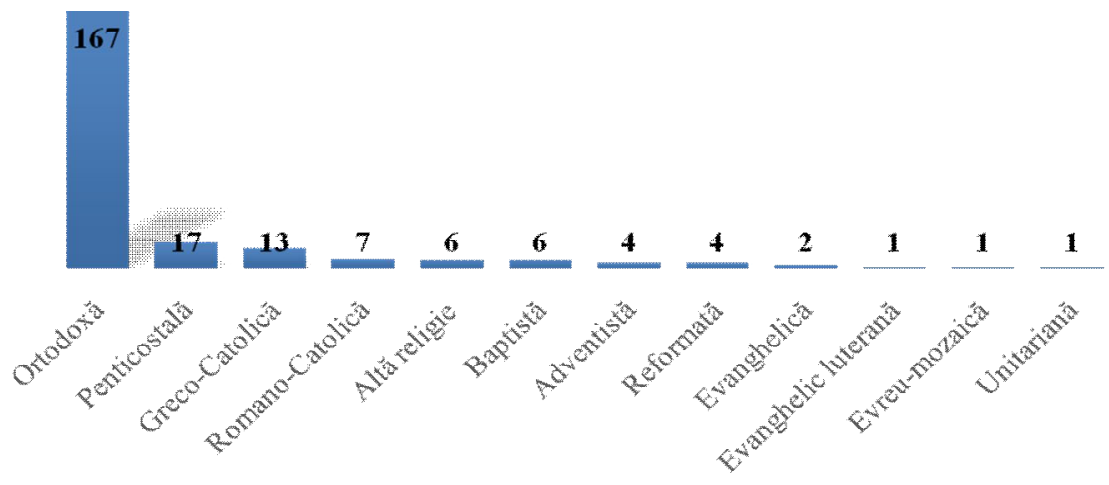

Figura 5. Distribuția participanților în funcție de cultul declarat

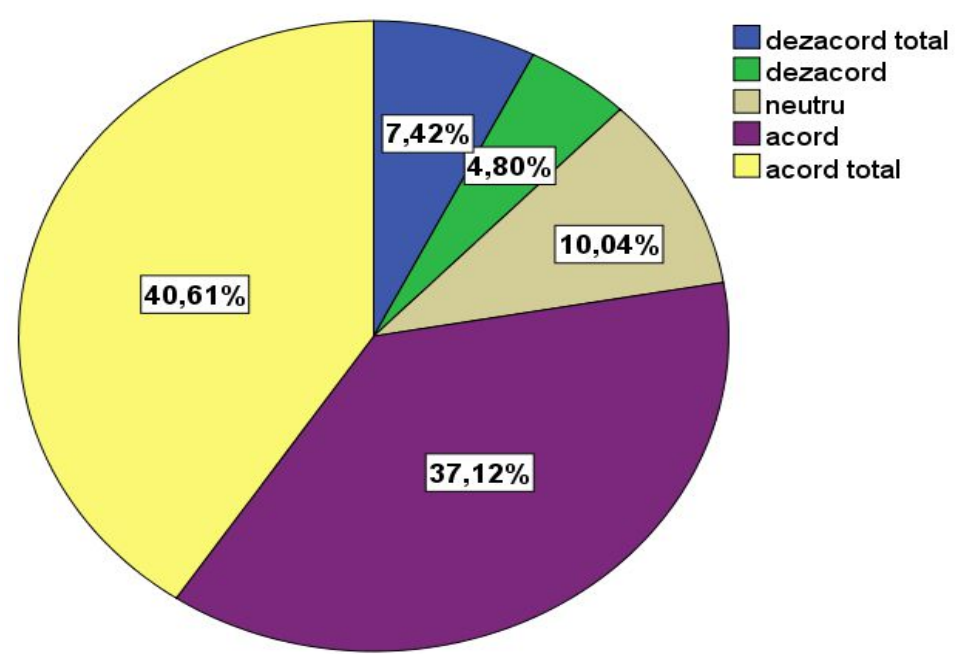

Figura 6. Reprezentarea procentuală privind intensitatea religiozităţii

În ceea ce privește trăirile emoționale raportate la credința în Dumnezeu, după cum se poate observa în figura 7 , majoritatea participanților la studiu (N=144) experimentează emoții de bucurie, un alt număr suficient de consistent trăiesc emoții de uimire $(\mathrm{N}=52)$ 
și tristețe $(\mathrm{N}=30)$, iar alte tipuri de trăiri emoționale, mai ales emoții negative și disfuncționale cum sunt, frica, vina, iritarea, dezgustul, rușinea, anxietatea, furia, disprețul, mândria și disperarea sunt experiențiate în contextul credinței religioase de un număr foarte mic de participanți la studiu. Din totalul participanților, $N=15$ au declarat că nu experimentează nici o trăire emoțională în raport cu credința religioasă, majoritatea dintre aceștia fiind participanții la studiu din categoria celor care au declarat că nu cred în Dumnezeu și s-au declarat non-religioși.

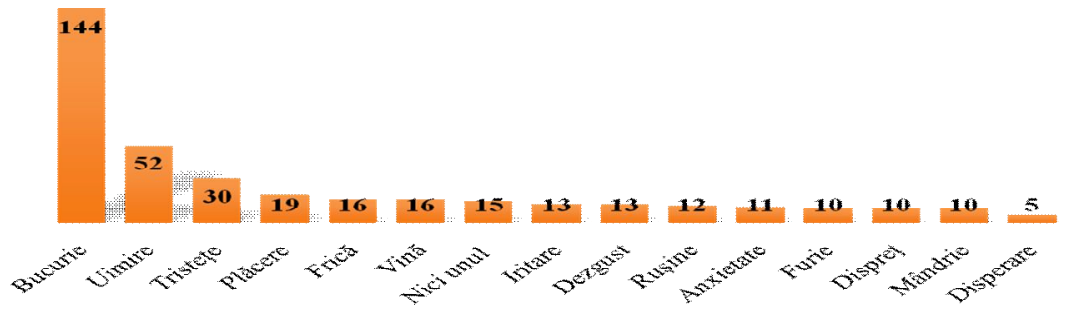

Figura 7. Distribuția răspunsurilor privind trăirile emoţionale raportate la evenimente sau manifestări religioase

\section{Formarea grupurilor de participanți}

În vederea testării predicţiei 3 a studiului am format trei grupuri de participanți pe baza criteriului nivelului de satisfacție în fața vieții înregistrat la scala de satisfacție a vieții, astfel grupul nr 1 prezintă un nivel scăzut al satisfacției în fața vieții $(n=30, \mathrm{SS})$, grupul nr. 2 manifestă un nivel mediu de satisfacție în fața vieții $(n=$ $57, \mathrm{SM})$, iar al treilea grup manifestă un nivel crescut al satisfacţiei în fața vieții $(n=165)$.

\begin{tabular}{|c|c|c|c|c|c|c|}
\hline VIRTUTI/ & Grupul & Grupul & Grupul & df & F & Eta $^{2}$ \\
Valori-în-acțiune & $\mathbf{1}$ & $\mathbf{2}$ & $\mathbf{3}$ & & & parțial \\
conform & SS & SM & SC & & & \\
modelului VIA & N=30 & N=57 & N=165 & & & \\
& M/AS & M/AS & M/AS & & & \\
& & & & & & \\
\hline
\end{tabular}




\section{I. ÎNŢELEPCIUNEA \\ SI CUNOASTEREA}

\begin{tabular}{|c|c|c|c|c|c|c|}
\hline 1. Curiozitatea & $\begin{array}{r}7,23 \\
(1.27) \mathrm{a}\end{array}$ & $\begin{array}{r}7,01 \\
(1,62) \mathrm{a}\end{array}$ & $\begin{array}{r}7,44 \\
(1,38) \mathrm{a}\end{array}$ & 2 & 0,13 & .016 \\
\hline $\begin{array}{l}\text { 2. Plăcerea de a } \\
\text { învăța }\end{array}$ & $\begin{array}{r}7,13 \\
(1,52) \mathrm{a}\end{array}$ & $\begin{array}{r}7,45 \\
(1,38) \mathrm{a}\end{array}$ & $\begin{array}{r}7,77 \\
(1,36) \mathrm{a}\end{array}$ & 2 & 3,25 & .026 \\
\hline $\begin{array}{l}3 . \\
\text { Discernământul }\end{array}$ & $\begin{array}{r}7,26 \\
(1,41) \mathrm{a} \\
\end{array}$ & $\begin{array}{r}7,35 \\
(1,38) \mathrm{a} \\
\end{array}$ & $\begin{array}{r}7,74 \\
(1,26) \mathrm{a} \\
\end{array}$ & 2 & 3,32 & .026 \\
\hline 4. Inventivitatea & $\begin{array}{r}7,03 \\
(1,32) \mathrm{a}\end{array}$ & $\begin{array}{r}7,24 \\
(1,67) \mathrm{a}\end{array}$ & $\begin{array}{r}7,60 \\
(1,33) \mathrm{a}\end{array}$ & 2 & 2,88 & .023 \\
\hline $\begin{array}{l}\text { 5. Inteligenţa } \\
\text { socială }\end{array}$ & $\begin{array}{r}7,03 \\
(1,42) \mathrm{a}\end{array}$ & $\begin{array}{r}6,91 \\
(1,72) \mathrm{a}\end{array}$ & $\begin{array}{r}7,90 \\
(1,46) \mathrm{ab}\end{array}$ & 2 & $13,21^{*}$ & .096 \\
\hline $\begin{array}{l}\text { 6. Simţul } \\
\text { perspectivei }\end{array}$ & $\begin{array}{r}7,43 \\
(1,13) \mathrm{a} \\
\end{array}$ & $\begin{array}{r}7,47 \\
(1,26) \mathrm{a} \\
\end{array}$ & $\begin{array}{r}7,95( \\
1,12) \mathrm{b} \\
\end{array}$ & 2 & $5,26^{*}$ & .041 \\
\hline \multicolumn{7}{|l|}{ II. CURAJUL } \\
\hline 7. Vitejia & $\begin{array}{r}5,53 \\
(1,73) \mathrm{a} \\
\end{array}$ & $\begin{array}{r}6,47 \\
(1,60) \mathrm{b} \\
\end{array}$ & $\begin{array}{r}7,00 \\
(1,44) \mathrm{c} \\
\end{array}$ & 2 & $12,86^{*}$ & .094 \\
\hline 8. Perseverenţa & $\begin{array}{r}7,20 \\
(1,56) \mathrm{a}\end{array}$ & $\begin{array}{r}6,78 \\
(1,83) \mathrm{a}\end{array}$ & $\begin{array}{r}7,43 \\
(1,83) \mathrm{b}\end{array}$ & 2 & $3,71^{*}$ & .029 \\
\hline 9. Integritatea & $\begin{array}{r}7.93 \\
(1,22) \mathrm{a}\end{array}$ & $\begin{array}{r}7,61 \\
(1,37) \mathrm{a} \\
\end{array}$ & $\begin{array}{r}8,12 \\
(1,27) \mathrm{b} \\
\end{array}$ & 2 & $3,36^{*}$ & .027 \\
\hline \multicolumn{7}{|c|}{$\begin{array}{l}\text { III. UMANITATEA } \\
\text { ŞI IUBIREA }\end{array}$} \\
\hline 10. Bunătatea & $\begin{array}{r}7,46 \\
(1,63) \mathrm{a} \\
\end{array}$ & $\begin{array}{r}7,08 \\
(1,59) \mathrm{a} \\
\end{array}$ & $\begin{array}{r}7,65 \\
(1,30) \mathrm{b} \\
\end{array}$ & 2 & $3,40^{*}$ & .027 \\
\hline $\begin{array}{l}\text { 11. Capacitatea } \\
\text { de a iubi şi a te } \\
\text { lăsa iubit }\end{array}$ & $\begin{array}{r}7,13 \\
(1,67) \mathrm{a}\end{array}$ & $\begin{array}{r}7,01 \\
(1,45) \mathrm{a}\end{array}$ & $\begin{array}{r}7,84 \\
(1,57) \mathrm{b}\end{array}$ & 2 & $7,26^{*}$ & .055 \\
\hline \multicolumn{7}{|l|}{ IV. DREPTATEA } \\
\hline $\begin{array}{l}12 . \\
\text { Responsabilitatea } \\
\text { cetăţenească }\end{array}$ & $\begin{array}{r}6,70 \\
(1,46) \mathrm{a}\end{array}$ & $\begin{array}{r}6,29 \\
(1,60) \mathrm{a}\end{array}$ & $\begin{array}{r}6,81 \\
(1,58) \mathrm{a}\end{array}$ & 2 & 2,25 & .018 \\
\hline $\begin{array}{l}13 . \\
\text { Imparţialitatea }\end{array}$ & $\begin{array}{r}6,86 \\
(1,69) \mathrm{a}\end{array}$ & $\begin{array}{r}6,35 \\
(1,65) \mathrm{a}\end{array}$ & $\begin{array}{r}7,01 \\
(1,54) \mathrm{b}\end{array}$ & 2 & $3,67^{*}$ & .029 \\
\hline 14. Spiritul de & 6,16 & 6,80 & 7,10 & 2 & $4,31 *$ & .033 \\
\hline
\end{tabular}




\begin{tabular}{|c|c|c|c|c|c|c|}
\hline conducere & $(1,85) \mathrm{a}$ & $(1,54) \mathrm{a}$ & $(1,63) \mathrm{ab}$ & & & \\
\hline \multicolumn{7}{|c|}{ V. CUMPĂTAREA } \\
\hline $\begin{array}{l}15 . \\
\text { Autocontrolul }\end{array}$ & $\begin{array}{r}5,70 \\
(1,74) a\end{array}$ & $\begin{array}{r}6,21 \\
(1,85) \mathrm{a}\end{array}$ & $\begin{array}{r}6,52 \\
(1,64) \mathrm{ab}\end{array}$ & 2 & $3,20 *$ & .042 \\
\hline 16. Prudenţa & $\begin{array}{r}5.76 \\
(1,56) a\end{array}$ & $\begin{array}{r}5,71 \\
(1,44) \mathrm{a}\end{array}$ & $\begin{array}{r}6,09 \\
(1,48) a\end{array}$ & 2 & 1,63 & .013 \\
\hline 17. Umilinţa & $\begin{array}{r}7,03 \\
(1,62) \mathrm{a} \\
\end{array}$ & $\begin{array}{r}6,80 \\
(1,43) \mathrm{a} \\
\end{array}$ & $\begin{array}{r}6,52 \\
(1,56) \mathrm{a} \\
\end{array}$ & 2 & 1,78 & .014 \\
\hline \multicolumn{7}{|c|}{ VI. TRANSCENDENŢA } \\
\hline $\begin{array}{l}\text { 18. Aprecierea } \\
\text { frumuseţii }\end{array}$ & $\begin{array}{r}7,46 \\
(1,43) \mathrm{a} \\
\end{array}$ & $\begin{array}{r}7,75 \\
(1,63) \mathrm{b} \\
\end{array}$ & $\begin{array}{r}8,27 \\
(1,21) \mathrm{c}\end{array}$ & 2 & $6,53^{*}$ & .050 \\
\hline 19. Gratitudinea & $\begin{array}{r}7,23 \\
(1,56) \mathrm{a}\end{array}$ & $\begin{array}{r}7,78 \\
(1,60) \mathrm{a}\end{array}$ & $\begin{array}{r}8,41 \\
(1,45) \mathrm{ab} \\
\end{array}$ & 2 & $9,86^{*}$ & .073 \\
\hline 20. Speranţa & $\begin{array}{r}6,13 \\
(1.38) a\end{array}$ & $\begin{array}{r}6,54 \\
(1,38) a\end{array}$ & $\begin{array}{r}7,52 \\
(1,39) \mathrm{ab}\end{array}$ & 2 & $19,52 *$ & .136 \\
\hline $\begin{array}{l}21 . \\
\text { Spiritualitatea }\end{array}$ & $\begin{array}{r}6,26 \\
(1,81) \mathrm{a} \\
\end{array}$ & $\begin{array}{r}7,10 \\
(1,30) \mathrm{b} \\
\end{array}$ & $\begin{array}{r}8,16 \\
(1,45) \mathrm{c} \\
\end{array}$ & 2 & $26,98^{*}$ & .179 \\
\hline 22. Iertarea & $\begin{array}{r}7,43 \\
(1,27) \mathrm{a}\end{array}$ & $\begin{array}{r}7,36 \\
(1,73) \mathrm{a}\end{array}$ & $\begin{array}{r}8,04 \\
(1,37) \mathrm{b}\end{array}$ & 2 & $5,81 *$ & .045 \\
\hline $\begin{array}{l}\text { 23. Simţul } \\
\text { umorului }\end{array}$ & $\begin{array}{r}7,23 \\
(1,40) a \\
\end{array}$ & $\begin{array}{r}7,17 \\
(1,35) \mathrm{a}\end{array}$ & $\begin{array}{r}7,28 \\
(1,49) \mathrm{a} \\
\end{array}$ & 2 & .124 & .001 \\
\hline 24. Entuziasmul & $\begin{array}{r}6,60 \\
(1,22) \mathrm{a}\end{array}$ & $\begin{array}{r}6,64 \\
(1,25) \mathrm{a}\end{array}$ & $\begin{array}{r}7,63 \\
(1,60) \mathrm{ab}\end{array}$ & 2 & $16,25^{*}$ & .115 \\
\hline
\end{tabular}

Notă: Adnotările diferite $(a, b, c)$ relevă diferenţe semnificative între grupuri în urma analizei univariate de varianţăşi a comparaţiilor post hoc, utilizând procedura Tukey HSD la * p <.05; SS = Nivel scăzut al satisfacţiei faţă de viaţă; SM = Nivel mediu al satisfacţiei faţă de viaţă; $\mathrm{SC}=$ Nivel crescut al satisfacţiei faţă de viaţă;

Tabelul nr. 1

Pe baza analizei univariate de varianţă şi a unor comparaţii post-hoc, utilizând procedura Tukey HSD, am constat următoarele diferenţe semnificative privind valorile în acţiune în funcţie de nivelul de satisfacţie în faţa vieţii:

- există diferenţe semnificative privind inteligenţa socială între grupul cu un nivel scăzut al satsifacţiei faţă de viaţă 
(SS) şi grupul cu un nivel crescut al satisfacţiei faţă de viaţă (SC), precum şi între grupul cu un nivel mediu al satisfacţiei faţă de viaţă $(\mathrm{SM})$ şi grupul cu un nivel crescut al satisfacţiei faţă de viaţă $(\mathrm{SC})$, inteligența socialăînregistrând valorile cele mai mari în cazul grupului SC;

- există diferenţe semnificative privind simţul perspectivei între grupul cu un nivel mediu al satisfacţiei faţă de viaţă (SM) şi grupul cu un nivel crescut al satisfacţiei faţă de viaţă (SC), simțul perspectivei înregistrând valorile cele mai mari în cazul grupului SC;

- există diferenţe semnificative privind vitejia şi bravura între grupul cu un nivel scăzut al satisfacţiei faţă de viaţă (SS) şi grupul cu un nivel mediu al satisfacţiei faţă de viaţă (SM), precum şi între grupul cu un nivel scăzut al satisfacţiei faţă de viaţă (SS) şi grupul cu un nivel crescut al satisfacţiei faţă de viaţă $(\mathrm{SC})$, vitejia şi bravuraînregistrând valorile cele mai mari în cazul grupului SC;

- există diferenţe semnificative privind perseverența/hărnicia/sârguința între grupul cu un nivel mediu al satisfacţiei faţă de viaţă (SM) şi grupul cu un nivel crescut al satisfacţiei faţă de viaţă (SC), perseverența/hărnicia/sârguințaînregistrând valorile cele mai mari în cazul grupului SC;

- există diferenţe semnificative privind integritatea/sinceritatea/onestitate între grupul cu un nivel mediu al satisfacţiei faţă de viaţă (SM) şi grupul cu un nivel crescut al satisfacţiei faţă de viaţă (SC), integritatea/sinceritatea/onestitateaînregistrând valorile cele mai mari în cazul grupului SC;

- există diferenţe semnificative privind bunătatea şi generozitateaîntre grupul cu un nivel mediu al satisfacţiei faţă de viaţ̧ă (SM) şi grupul cu un nivel crescut al satisfacţiei faţă de viaţă (SC),bunătatea şi generozitateaînregistrând valorile cele mai mari în cazul grupului SC; 
- există diferenţe semnificative privind capacitatea de a iubi şi a te lăsa iubitîntre grupul cu un nivel mediu al satisfacţiei faţă de viaţă (SM) şi grupul cu un nivel crescut al satisfacţiei faţă de viaţă ( $\mathrm{SC}$ ), capacitatea de a iubi şi a te lăsa iubitînregistrând valorile cele mai mari în cazul grupului $\mathrm{SC}$;

- există diferenţe semnificative privind imparţialitatea şi echitateaîntre grupul cu un nivel mediu al satisfacţiei faţă de viaţă (SM) şi grupul cu un nivel crescut al satisfacţiei faţă de viaţă (SC), imparţialitatea şi echitateaînregistrând valorile cele mai mari în cazul grupului $\mathrm{SC}$;

- există diferenţe semnificative privind spiritul de conducereîntre grupul cu un nivel scăzut al satisfacţiei faţă de viaţă (SS) şi grupul cu un nivel crescut al satisfacţiei faţă de viaţă $(\mathrm{SC})$, spiritul de conducereînregistrând valorile cele mai mari în cazul grupului $\mathrm{SC}$;

- există diferenţe semnificative privind autocontrolulîntre grupul cu un nivel scăzut al satisfacţiei faţă de viaţă (SS) şi grupul cu un nivel crescut al satisfacţiei faţă de viaţă (SC), autocontrolulînregistrând valorile cele mai mari în cazul grupului $\mathrm{SC}$;

- există diferenţe semnificative privind aprecierea frumuseţii şi a calităţii între grupul cu un nivel scăzut al satisfacţiei faţă de viaţă (SS) şi grupul cu un nivel crescut al satisfacţiei faţă de viaţă (SC), precum şi între grupul cu un nivel mediu al satisfacţiei faţă de viaţă (SM) şi grupul cu un nivel crescut al satisfacţiei faţă de viaţă (SC), aprecierea frumuseţii şi a calităţii înregistrând valorile cele mai mari în cazul grupului $\mathrm{SC}$;

- există diferenţe semnificative privind gratitudinea între grupul cu un nivel scăzut al satisfacţiei faţă de viaţă (SS) şi grupul cu un nivel crescut al satisfacţiei faţă de viaţă (SC), precum şi între grupul cu un nivel mediu al satisfacţiei faţă de viaţă (SM) şi grupul cu un nivel crescut al satisfacţiei faţă 
de viaţă (SC), gratitudineaînregistrând valorile cele mai mari în cazul grupului SC;

- există diferenţe semnificative privind speranţa/optimismul/dorința de planificare a viitorului între grupul cu un nivel scăzut al satisfacţiei faţă de viaţă (SS) şi grupul cu un nivel crescut al satisfacţiei faţă de viaţă (SC), precum şi între grupul cu un nivel mediu al satisfacţiei faţă de viaţă (SM) şi grupul cu un nivel crescut al satisfacţiei faţă de viaţă (SC), speranța/optimismul/dorinţa de planificare a viitoruluiînregistrând valorile cele mai mari în cazul grupului SC;

- există diferenţe semnificative privind spiritualitatea/simţul scopului/credința/ religiozitateaîntre grupul cu un nivel scăzut al satisfacţiei faţă de viaţă (SS) şi grupul cu un nivel mediu al satisfacţiei faţă de viaţă (SM), între grupul cu un nivel mediu al satisfacţiei faţă de viaţă $(\mathrm{SM})$ şi grupul cu un nivel crescut al satisfacţiei faţă de viaţă (SC),între grupul cu un nivel scăzut al satisfacţiei faţă de viaţă (SS)grupul cu un nivel crescut al satisfacţiei faţă de viaţă (SC)spiritualitatea/simţul

scopului/credința/religiozitateaînregistrând valorile cele mai mari în cazul grupului SC;

- există diferenţe semnificative privind iertarea şi mila între grupul cu un nivel mediu al satisfacţiei faţă de viaţă (SS) şi grupul cu un nivel crescut al satisfacţiei faţă de viaţă (SC), iertarea şi milaînregistrând valorile cele mai mari în cazul grupului $\mathrm{SC}$;

- există diferenţe semnificative privind verva/pasiunea/entuziasmul între grupul cu un nivel scăzut al satisfacţiei faţă de viaţă (SS) şi grupul cu un nivel crescut al satisfacţiei faţă de viaţă (SC), precum şi între grupul cu un nivel mediu al satisfacţiei faţă de viaţă (SM) şi grupul cu un nivel crescut al satisfacţiei faţă de viaţă (SC), verva/pasiunea/entuziasmulînregistrând valorile cele mai mari în cazul grupului SC; 
- nu s-au constatat diferenţe semnificative între cele trei grupuri (SS, SM, SC) privind următoarele valori în acţiune: curiozitatea, plăcerea de a învăţa, discernământul, inventivitatea, responsabilitatea cetăţenească, prudenţa, umilinţa şi simţul umorului.

\section{Concluzii}

In raport cu predicţiile studiului putem constata că:

- majoritatea persoanelor care se declară credincioase şi au un nivel crescut de religiozitate manifestă un nivel crescut de satisfacţie a vieţii $(n=165)$;

- majoritatea participanţilor la studiu trăiesc emoţii pozitive şi funcţionale cum ar fi emoţii de bucurie $(n=144)$, sau emoţii de uimire $(n=52)$ în momentul în care se raportează la diverse evenimente sau manifestări religioase;

- majoritatea valorilor în acţiune înregistrează scorurile cele mai mari, semnificative statistic la nivelul grupului de persoane care cred în Dumnezeu cu un nivel crescut al religiozităţii măsurat prin intensitatea credinţei autodeclarate şi un nivel crescut al satisfacţiei faţă de viaţă comparativ cu grupurile de persoane care au un nivel scăzut $(n=30)$, sau mediu(n=57)al satisfacţiei faţă de viaţă

- valorile în acţiune care sunt operaţionalizate la nivelul grupului cu nivel crescut al satisfacţiei faţă de viaţă sunt: inteligenţa socială, simţul perspectivei din cadrul virtuţii Înţelepciune şi cunoaştere, vitejia şi bravura,perseverenţa/hărnicia/sârguinţa şi integritatea/sinceritatea/onestitatea din cadrul virtuţii Curaj, bunătatea şi generozitatea, capacitatea de a iubi şi a te lăsa iubit din cadrul virtuţiiUmanitate şi Iubire, imparţialitatea şi echitatea şi spiritul de conducere din cadrul virtuţiiDreptate, autocontrolul din cadrul virtuţii Cumpătare, aprecierea frumuseţii şi a calităţii, gratitudinea, speranţa/optimismul/dorinţa de planificare a viitorului, spiritualitatea/simţul scopului/credinţa/religiozitatea, iertarea şi mila verva/pasiunea/entuziasmul din cadrul virtuţii Transcendenţă. 


\section{Limite ale studiului}

- validarea în curs a chestionarului VIA pe populație românească;

- măsurarea religiozității doar prin credința autodeclarată;

- majoritatea participanților la studiu au fost de religie ortodoxă

- majoritatea participanților la studiu au fost din Transilvania.

Aceste studiu aduce o serie de dovezi științifice despre importanța valorilor în acțiune în contextul religiozității, punând încă o dată în lumină de pe poziția psihologiei pozitive că educaţia religioasă, credinţa în Dumnezeu şi contextul cultural sprijină dobândirea virtuţilor prin instituţii, ritualuri, modele de rol, parabole, maxime şi poveşti motivationale (Seligman, 2002), crescând în mod implicit satisfacția față de viață a oamenilor.

\section{Bibliografie}

1. Allen, D. (1997). Ascetic theology and psychology. In Limning the Psyche: Explorations in Christian Psychology (Eds. R.C. Roberts, M.R. Talbot), pp. 297-316. Grand Rapids, MI: Eerdmans.

2. Barrett, L.F. (2006). Solving the emotion paradox: Categorization and the experience of emotion, Personality and Social Psychology Review, 10, 20-46.

3. Barrett, L.F. (2006). Are emotions natural kinds?, Perspectives on Psychological Sciences, Volum 1, Issue 1, 28-58.

4. Ekman, P. (1994). Moods, Emotions and Traits. In Ekman P. şi Davidson, R. (Eds.), The Nature of Emotion Questions. New York: Oxford University Press.

5. Emmons, R.A. (1999). The psychology of ultimate concerns: Motivation and spirituality in personality. New York: The Guilford Press.

6. Emmons, R.A., Paloutzian, R.F. (2003). The Psychology of Religion, Annual Review of Psychology, 54:377-402.

7. George LK, Larson DB, Koenig HK, McCullough ME. 2000. Spirituality and health: Annu. Rev. Psychol. 2003.54:377-402.

8. Gillani N.B., Smith. J.C. (2001). Zen meditation and ABC relaxation theory: an exploration of relaxation states, beliefs, dispositions, and motivations. Journal of Clinical Psychology. 57: 839-846. 
9. Gross, J.J. (2002). Emotion regulation: affective, cognitive, and social consequences. Psychophysiology 39: 281-291

10. Haidt, J. (2003). The moral emotions. In R.J. Davidson, K.R. Scherer şi H.H. Goldsmith (Ed.), Handbook of affective sciences (pp. 852-870). Oxford: Oxford University Press.

11. Hill, P.C. (1999). Giving religion away: what the study of religion offers psychology. International Journal of Psychological Religion. 9:229-249.

12. McCauley, R.N. (2001). Ritual, memory, and emotion: comparing two cognitive hypotheses See Andresen 2001, pp. 115-140.

13. McCraty, R., Barrios-Choplin, B., Rozman, D., Atkinson, M., Watkins, A.D. (1998). The impact of a new emotional self-management program on stress, emotions, heart rate variability, DHEA and cortisol. Integrative Physiology and Behavioral Science. 33:151-170.

14. Opriş, D., Opriş, M. (2015). Valori, modele şi aşteptări ale liceenilor din judeţul Alba, Ed. Eikon, Cluj-Napoca.

15. Paloutzian, R. F., \& Park, C. L (2005). Emotion and religion In R. F. Paloutzian \& C. L. Park (eds.), Handbook of the psychology of religion and spirituality (pp. 37-52). New York: Guilford Press.

16. Paloutzian, R. F., \& Park, C. L (2005). Integrative themes in the current science of the psychology of religion. In R. F. Paloutzian \& C. L. Park (eds.), Handbook of the psychology of religion and spirituality (pp. 3-20). New York: Guilford Press.

17. Peterson, C., Seligman M. (2002). The VIA Taxonomy of Human Strengths and Virtues. Washington, DC: American Psychological Association. 18. Roşan, A.. (2015), Câteva reflecţii psihologice privind emoția şi virtutea într-o sociologie a seninătăţii, în Iluţ, P. (coord), Dragoste, familie şi fericire. Spre o sociologie a seninătăţii, Edit. Polirom, Iaşi.

19. Sandage, S.J., Hill, P.C. (2001). The virtues of positive psychology: therapprochement and challenges of an affirmative postmodern perspective. Journal of Theory Social Behaviour, 31:241-260

20. Seligman, M.E.P (2002). Authentic Happiness, New York: Free Press.

21. Seligman, M.E.P., Csikszentmihalyi, M. (2000). Positive psychology: an introduction. American Psychology, 55:5-14.

22. Silberman, I, ed. (2003). Religion as a meaning system. Journal of Social Issues.

23. Snyder, C.R., McCullough, M.E. (2000). A positive psychology field of dreams: "If you build it, they will come ..." Journal of Social and Clinical Psychology, 19:151-160.

24. Watts, F.N. (1996). Psychological and religious perspectives on emotion. International Journal of Psychology and Religion. 6:71-87. 